Resumen por el autor, J. M. D. Olmsted.

El papel del sistema nervioso en la locomoción de ciertos policládidos marinos.

Los policládidos Planocera californica, Phylloplana littoricola y Leptoplana saxicola exhiben cuantro tipos posibles de locomoción. Para los movimientos de natación es necesario que los ganglios cefálicos estén intactos. La destrucción parcial o la pérdida del cerebro impide el uso de este método de locomoción. La acción ciliar no está regulada por el sistema nervioso y prácticamente no juega papel alguno en la locomoción. La locomoción atáxica es un fenómeno puramente local, pero está regulado por el sistema nervioso, puesto que puede abolirse por la cloretona. Euryleptotes cavicola se mueve por este tipo de locomoción solamente. La locomoción retrógrada detáxica está regulada por los ganglios cefálicos, cada ganglio regulando la progresión de la olas musculares de su mismo lado. Los cordones nerviosos sirven como conductores de los impulsos para la formación de las ondas de su mismo lado. Cuando se corta un nervio las ondas desaparecen en el mismo lado de la operación al nivel de la sección. La locomoción de los policládidos es comparable en este respecto a la de los moluscos.

Translation by José F. Nonidez

Cornell Medical College, New York 


\title{
THE RÔLE OF THE NERVOUS SYSTEM IN THE LOCOMOTION OF CERTAIN MARINE POLYCLADS
}

\author{
J. M. D. OLMSTED
}

Hopkins Marine Station of Stanford University and University of Toronto

During experiments on the regeneration of polyclad turbellaria of Monterey Bay, California, it was noticed that there were pronounced changes in locomotion following certain operations which involved the central nervous system.

Three species were studied with reference to the control of locomotion by the nervous system, Planocera californica, Phylloplana littoricola, and Leptoplana saxicola, with a few observations on Euryleptotes cavicola. The methods of locomotion are the same in the first three species, the chief differences lying in the rate of progression- $\mathrm{L}$. saxicola being the fastest moving and $P$. californica the slowest-and also in the relative frequency of each method in the different species.

A general account of the locomotion of polyclads is given by Lang ('84) in his monograph on the polyclads from the Bay of Naples. A more detailed account of the locomotion of Leptoplana tremellaria, also from the Bay of Naples, is given by Child ('04), and of Leptoplana lactoalba var. tincta from Bermuda by Crozier ('18). Child states that there are two chief methods of movement in L. tremellaria, 'swimming and creeping.' The former is an 'undulating movement' of the margins of the body, the latter involves 'both muscular and ciliary activity.' "When the animal is moving quietly - the cilia afford the chief motive power, although the slight muscular movements of the margin of the body are almost constant, portions being lifted from the substratum, brought forward, and again attached." But when strongly stimulated, "movements occur in rapid alternation on the two 
sides of the body and the similarity between this mode of progression and the use of legs cannot escape the observer." This is a type of locomotion common to gastropods and is called retrograde detaxic (Olmsted, '17). This type of locomotion was observed by Crozier to occur in his Bermudian species. The methods of locomotion described by these authors are seen in the species of polyclads from Monterey Bay, but they are in reality four distinct methods of progression.

In these species the swimming movement involves the whole body, not merely the lateral margins as in Leptoplana tremellaria (Child, '04). P. californica resorts to this method more frequently than the other species. E. cavicola was never seen to release itself from the substrate, and therefore never swam freely. While creeping about a dish, P. californica will suddenly release its anterior end, raise it above the substrate, and initiate a series of waves which, from their resemblance to gastropod locomotion, may be termed retrograde monotaxic (Olmsted,'17). The resulting movement is like that of a rug being rapidly shaken. The waves appear at the rate of two a second, and pass posteriorly at such a rate that two or two and a half waves are present at a given moment. An individual seldom swam more than $2 \mathrm{~cm}$. in this fashion before resuming its creeping. The other two species seldom employed this method of locomotion except when falling through the water after creeping along the under side of the surface film, or when somewhat roughly dislodged from the substrate during active creeping. Swimming was never initiated from rest, but only occurred if the animal were already in motion. In this type of locomotion either the dorsal or ventral surface might be uppermost, the dorsal more often in P. littoricola.

When transverse cuts were made at any level posterior to the cephalic ganglia of these polyclads, this swimming movement could no longer be elicited from brainless posterior pieces, but the anterior pieces containing the brain, no matter how short, exhibited a few swimming movements when falling from the surface. Likewise after splitting the head longitudinally so that the two halves of the brain were separated, an animal could not be made to swim, even if one cephalic ganglion remained in each 
piece. The brain must therefore be intact for this movement to take place. The wave of muscular contraction in this method of locomotion involves the coordinated movements of both sides of the body, for the wave extends across the entire width of the animal. One might imagine that each cerebral ganglion could control the movements on its own side, and in those individuals with the brain split in halves each side might act independently. But this proved not to be the case. It was necessary that the entire brain be undisturbed. Again, it would seem reasonable that the impulse to start off this method of locomotion might originate from some stimulus at the anterior end of the worm, since preliminary movements are made by this portion before releasing the rest of the body from the substrate in preparation for swimming. But if the anterior ends were removed by a transverse cut immediately in front of the cephalic ganglia, it was found that the anterior brainless pieces were unable to swim, while the posterior pieces retained this power perfectly. The impulse to initiate the wave seems therefore not to occur as a stimulus from the anterior part of the body, but from within the brain itself.

When the cephalic ganglia were removed by cutting out a small disc of tissue in the vicinity of the eyes, and the hole had filled in by regeneration, it was found that the brain could not be regenerated. Such brainless worms were unable to swim although no part was lacking except the brain.

Ciliary movement does not play a prominent part in the locomotion of these four species of polyclads. When they are apparently at rest and making absolutely no progress at all, the cilia can be seen still beating. When the worms are placed in chloretone, the cilia dontinue to beat, and if a worm becomes detached from the substrate to which it often adheres even when anesthetized, it will be carried along at a very slow rate by the eilia. The speed is the same whether the worm is on its dorsal or ventral surface, and is slower than any method of locomotion by muscular action. I am convinced that the cilia never function as the sole organs of locomotion under normal conditions. They may aid muscular locomotion, but do not act 
alone. Miss Stringer ('17) has made this same criticism of the accepted view of the means of locomotion in the triclad planarians and Crozier ('18) claims that in the Leptoplana 'tincta' "when muscular waves are absent, no creeping progression can be detected." Pieces of any size and from any portion of the body of the Monterey polyclads show this same ciliary movement in chloretone. This ciliary action is therefore not dependent on the central nervous system.

The slow creeping movement is accomplished by means of the constant slight muscular contractions to which Child ('04) refers. There are no definite waves, but the entire ventral surface appears to be thrown into irregular ripples. This can be especially well observed when the polyclad is creeping under the surface film of the water. E. cavicola is especially favorable for observation, since the animal is a broad oval, some $3 \mathrm{~cm}$. in length by 2 in width. The animal lays down a track of mucus as it proceeds. The midventral region is depressed and fairly quiet, as if this portion were holding on by suction, while the margins are especially active. The rippling motion is due to momentary local release of a portion of the ventral surface from its point of attachment and a shifting of this area by muscular contraction. These worms are able to go both forwards and backwards and to turn to one side. The movement is slow and often irregular. Pieces formed by longitudinal cuts always moved in circles toward the injured side (cf. Child). With P. californica and E. cavicola the rate of progress averaged some $0.5 \mathrm{~mm}$. per second. The other species moved slightly faster, but so seldom in a straight line that accurate measurements were not obtained. Worms with the cephalic ganglia removed and pieces from any region anterior or posterior to the brain exhibited this ataxic (Olmsted, '17) type of locomotion. The rippling muscular movement persisted for some fifteen minutes in a saturated solution of chloretone in seawater, but finally ceased if the animal were undisturbed. The slow creeping movement is therefore under control of that part of the nervous system in the immediate locality of each muscular contraction and is a local phenomenon. 
Of the fourth type of movement Child makes the following remark, "The animals appear almost as if walking forward." This ditaxic retrograde locomotion is brought about by the releasing of a small portion of the lateral margin at the anterior end of the worm, the pulling of this bit forward 2 or $3 \mathrm{~mm}$. by contraction of the longitudinal muscles, and its reattachment at a point anterior to its former position. The contraction once started proceeds in a wave down the entire margin to the posterior end. These waves alternate on each side of the body, so that the worm appears to stride along like a biped. This agrees in every respect with the process in gastropods. From records of observations on one large specimen of $\mathrm{P}$. californica, the rate of slow ditaxic locomotion is $0.21 \mathrm{~cm}$. per second, and the worm takes 0.33 step per second. Other records on the same individual gave $0.36 \mathrm{~cm}$. and 0.4 step per second. When disturbed it could proceed at the rate of $0.39 \mathrm{~cm}$. per second in $0.66 \mathrm{step}$. The rate of locomotion may therefore be varied both by an increase in the number of steps and the length of each step as well. For P. littoricola the ordinary movement was more rapid, i.e., $0.4 \mathrm{~cm}$. per second in 0.11 step. When disturbed, there was very little increase $-0.43 \mathrm{~cm}$. in $0.13 \mathrm{step}$. This type of locomotion was not observed in E. cavicola.

To determine whether the wave was initiated in the margin of the head, this portion was cut away. It was then found that waves started just posterior to the cut, but their rate was practically normal. In another experiment a semicircular cut in front of the brain of $\mathrm{L}$. saxicola severed the connection of the nerves of the anterior margin with the brain. This worm exhibited the walking movement perfectly, the waves starting on a level with the ends of the cut. The cut healed over in three days, and by the fourth day locomotion was perfectly normal, the waves starting at the anterolateral margin of the head. Headless specimens and those with the cephalic ganglia removed were unable to employ this type of locomotion, but anterior pieces from worms transected just behind the brain nearly always use this as their sole means of locomotion. 
Splitting the head through the brain usually resulted in loss of this ditaxic type of movement. In two cases, however, parts of the cerebral ganglia remained intact. In one of these the cut removed a portion of the right half of the brain. For a week after the operation this worm performed the walking movement with its left side perfectly and moved in circles to the right. Later, an occasional wave on the right alternated with those on the left. This imperfect coordination continued even after a month, so that the animal was never able to move in a straight line. In the other case the brain was evenly divided. Each piece regenerated all its parts except the missing half of the brain. The smaller piece which contained the left half of the brain moved in circles to the right by means of a single wave which took its origin at the usual point and passed down the left margin. There was never any indication of a wave in the new tissue on the right side during the month it was under observation. In the larger piece in which the left half of the brain was missing, waves passed down the right side quite normally with only an occasional alternate wave down the left side, so that this piece moved in circles to the left. By the end of a week, however, the waves on the left side made their appearance somewhat more frequently and alternated some two or three times with waves on the right side. These waves never appeared in the new tissue, they began posterior to the cut. The worm remained in this condition for more than a month, still circling to the left and lacking perfect coordination between the right and left halves of its body.

These experiments indicate that each cerebral ganglion controls the 'stepping movement' on its own side, each half being independent of the other. But for perfectly coordinated movements involving both sides of the body, the connection between the halves of the brain must be intact. In view of the fact that a few coordinated movements were possible in the two cases just described, where a portion or all of the brain had been removed from one side of the body, it is evident that a wave may appear on a side lacking the brain. But it must be remembered that there was at least one-half the brain present in the body, that the 
wave appeared only in the old tissue, never in the new, and that it appeared infrequently and only after several waves had passed down the uninjured side. I should explain the appearance of the wave on the side lacking its half of the brain on the ground that through the physiological principles of 'facilitation' and 'summation,' the movement of a wave down the uninjured side was able to serve as a stimulus, which, upon being transmitted through the connecting commissure immediately behind the brain to the other nerve cord, was sufficient to initiate an occasional wave. (Cf. the diagram of the ventral nervous system of L. saxicola given by Heath and McGregor, '12, fig. 21.)

If the stepping movement in ditaxic locomotion is controlled by the cephalic ganglia, the question arises as to the function of the longitudinal nerve cords. Various operations were tried in order to answer this question. It was found necessary to make observations fairly soon after cutting the nerve cords, for within three or four days a wound extending almost the entire width of the body would be joined together and perfect coordination restored. For example, in a specimen of L. saxicola a horizontal slit was made posterior to the brain, severing both nerve cords. The part anterior to the wound at once moved rapidly by the ditaxic method of locomotion and also attempted to swim freely in the water. The posterior part moved slowly by the ataxic method. The consequence was that the pulling of the anterior end caused the wound to gape in a wide circle. When the worm came to rest, the edges of the wound closed. Two days later the wound was healed and on the next day perfectly coordinated alternate waves passed down the entire length of the worm in a normal manner.

The nerve cords serve as conductors of impulses which cause progression of the waves in ditaxic locomotion. This is nicely shown by cutting a portion from the side of a worm without injuring the nerve cord. A wave starting at the head end of the body stops when it reaches the upper edge of the wound, for the muscles which would carry the wave on have been cut away. But the wave again makes its appearance at the proper time at the lower margin of the wound, and then continues on to the 
posterior end of the worm. The impulse therefore was carried on through the nerve cord, though there was no visible effect accompanying its passage. But if the wound were near enough to the midline to have cut into the nerve cord, the wave on that side ceased entirely at the level of the wound. According to the diagram of the nervous system of L. saxicola of Heath and McGregor, there is only one cross connective between the two nerve cords, and that is situated immediately posterior to the brain. If the wound is made anterior to this connective an occasional wave will pass down the injured side as explained above, but if the wound is posterior to this connective there can be no conduction of the impulse to form a muscular wave. Local muscular contraction can still take place, however. In one case a long strip was cut from one side of the body of a worm, leaving a narrow bridge of tissue at the anterior end to attach it to the body. The ditaxic waves stopped when they reached the bridge of tissue, and reappeared at the posterior edge of the wound. No wave appeared in the strip itself. One could cause the strip to contract by pricking any portion of it, so that the local muscular response remained. Within two days the strip was attached to the body except at the extreme posterior end, but no waves appeared in it when the worm was 'walking.' On the third day the wound was entirely healed and waves passed two-thirds of the way down the strip. On the following day the animal moved normally. The union of cut ends of the nerve cord or of severed peripheral branches with the brain or nerve cords occurred in a remarkably short time, since perfect coordination was established in a very few days. But if a piece of the nerve cord were actually removed, there was lack of coordination for several weeks, because of the relatively slow regeneration of lateral parts including the nerve cords. Nerve cords do regenerate, while the brain will not.

The locomotion of these polyclad worms is comparable in every respect with that of gastropod mollusks. The types of movement are the same. Retrograde monotaxic, retrograde alternate ditaxic, and ataxic methods are clearly distinguishable. The part played by the nervous system is similar in each group 
(cf. section of "Physiologie des Nervensystems," by S. Baglioni in Winterstein's "Handbuch der vergleichenden Physiologie"). Slugs are able to move by means of waves on the foot when the connection with the brain is severed. Waves can also appear on isolated pieces of the foot. 'This is correlated with the presence of an extensive nerve net in the foot with many cross connectives. Ataxic locomotion in the polyclads is likewise carried on in the absence of the brain and in pieces from any part of the body. Their nerve net must be responsible for this movement, since the movement is under the control of the nervous system in the immediate vicinity of the contracting muscles. In snails, such as Helix pomatia, the impulse which causes the normal peristaltic wave arises in the pedal ganglion, and is transmitted by the nerve cords of the foot, each of which serves a definite area. In a similar way both monotaxic and ditaxic locomotion of the polyclads are controlled by the cephalic ganglia, and the nerve cords transmit the impulses to a definite area. This is another instance of evolution along the same lines in two quite different groups.

\section{SUMMARY}

The polyclads, Planocera californica, Phylloplana littoricola, and Leptoplana saxicola, exhibit four possible types of locomotion.

For the swimming movement it is necessary that the cephalic ganglia be intact. Injury to or loss of the brain prevents the use of this method.

Ciliary action is not under the control of the nervous system and plays practically no part in locomotion.

Ataxic locomotion is a purely local phenomenon, but controlled by the nervous system since it is abolished by chloretone. Euryleptotes cavicola moves by this type of locomotion alone.

Ditaxic retrograde locomotion is under the control of the cephalic ganglia, each ganglion controlling the progression of muscular waves on its own side.

The nerve cords serve as conductors for the impulses to wave formation each on its own side. Cutting a nerve causes the waves to disappear on that side at the level of the cut.

The locomotion of polyclads is comparable in these respects with that of mollusks. 


\section{BIBLIOGRAPHY}

ChILd, C. M. 1904 Studies on regulation. IV. Some experimental modifications of form-regulation in Leptoplana. Jour. Exp. Zoöl., vol. 1, pp. 95-133.

Crozrer, W. J. 1918 On the method of progression in polyclads. Proc. Nat. Acad. Sci., vol. 4, pp. 379-381.

Heath, H., and McGregor, E. A. 1912 New polyclads from Monterey Bay, California. Proc. Acad. Nat. Sci. Phila., Sept., 1912, pp. 455-488.

Lang, A. 1884 Die Polycladen (Seeplanarien) des Golfes von Neapel. Leipzig.

Olmsted, J. M. D. 1917 Notes on the locomotion of certain Bermudian mollusks. Jour. Exp. Zoöl., vol. 24, pp. 223-236.

Stringer, C. E. 1917 The means of locomotion in planarians. Proc. Nat. Acad. Sei., Dec., 1917, pp. 691-692.

Wintersters, H. 1913 Handbuch der vergleichenden Physiologie, Bd. 4. Jena. 